\title{
Multivariate Analysis of Genetic Divergent of Ethiopian Mustard (Brasica Carinata A. Braun) Landraces in Relation to Oil Quality Component Traits
}

\author{
1*Fekadu Amsalu, ${ }^{2}$ Sentayehu Alamerew \\ ${ }^{1}$ Holetta Agricultural Research Center, Addis Ababa, Ethiopia. \\ ${ }^{2}$ Department of Plant science and Horticulture, Jimma University, Jimma, Ethiopia.
}

\begin{abstract}
The experiments was conducted at Holetta Agricultural Research Center, Ethiopia, to assess the extent and pattern of genetic variability of Ethiopian mustard land races with respect to oil content and its related component quality traits in Forty nine Ethiopian Mustard land races. The experiment was carried out in a simple lattice design. Univariate analysis of variance showed that there were highly significant differences among genotypes for all oil quality traits compared.The significant difference indicates the existence of genetic variability among the accessions that is important for selection and breeding program. Multivariate analyses resulted in the formation of four clusters and have shown the presence of extensive genetic diversity among the genotypes. Genetic distances were highly significant among most of the clusters. The highest genetic distance was recorded between Cluster 3 and Cluster 4 (38.2) followed by Cluster 1 and Cluster 4 (37.7), and Cluster 1 and Cluster 2 (33.3). The genetic divergence between Cluster 1 and Cluster 2, Cluster 1 and Cluster 4, Cluster 2 and Cluster 4, Cluster 3 and Cluster 4 were also highly significant. Genetic distances of land races based on seed oil quality traits between Cluster 2 and Cluster 3 were only non- significant, indicating close relationship among the genotypes. The present study also showed that geographical diversity could not necessarily be an index of variation and the factors other than geographic diversity such as genetic drift, selection pressure, closeness in pedigree and environment may be responsible for differential grouping of land races of genotypes of Ethiopian mustard.
\end{abstract}

Keywords: Ethiopian mustard, Genetic diversity, univariate analysis, multivariate analysis, oil quality traits

\section{INTRODUCTION}

The genus Brassica of Brassicaceae family as a whole is believed to have originated around the Mediterranean, Eastern Afghanistan and the adjoining portion of Pakistan and North-Eastern Africa (Hemigway, 1976). The genus includes six economically important species, namely, Brassica rapa, B. oleracea, B. nigra, B. juncea, B. napus, and B. carinata (Doweny and Röbbelen, 1989). Ethiopian mustard is believed to be originated in the highlands of the Ethiopian plateau and the adjoining portion of East Africa and the Mediterranean coast (Gomez-Campo and Prakash, 1999). It evolved as a natural cross between $B$. nigra $(\mathrm{BB})(\mathrm{n}=8)$ and $B$. oleracea $(\mathrm{CC})(\mathrm{n}=9)$ and underwent further chromosomal doubling $(2 n=34$; UN, 1935). It is partially amphidiploids. In Ethiopia, among the highland oilseeds, Ethiopian mustard stands third next to niger seed and linseed in total production and areas coverage (CSA, 2013/2014). Major production constraints of the Ethiopian mustard are: lack of high yielding, early maturing varieties, high erucic acid (C22:1) content in seed oil and high glucosinolate content in the meal (EARO, 2000). Before Ethiopian mustard can be used as a major food crop, the quality of both the seed oil and the meal characteristics must be improved to meet Canola quality standards (Getinet et al., 1994).Therefore in order to use Ethiopian mustard seed oil for food, none food industry and enhance its cultivation, different seed oil quality characteristics have to be satisfied.There are a choice of breeding strategies which enable the improvement of oil quality characteristics demanded by aforementioned of market segments (Alemayehu and Becker, 2001,Tekelwold,2005,Yared, 2010). Even if little effort have been done to improve oil quality of Ethiopian mustard seed using various breeding strategies much need to be done to utilize natural variations that might exist among population of the species of the crop for the fatty acid profile. Doing so may help for the future breeding procedure such as back crossing and development of agronomical feasible genotypes. Assessing the genetic diversity and the relationship among the Ethiopian mustard 
genotypes based on their seed oil quality traits is thus a precondition which may help in identifying important genotypes and selection criteria for the improvement of Ethiopian seed oil. Therefore the present study was, executed with the objective of assessing the extent and pattern of genetic diversity of Ethiopian mustard land races collected from diverse agro climatic regions of the country with respect to oil content and its component quality traits.

\section{MATERIALS AND MeTHODS}

\section{Experimental Site}

The experiment was conducted at Holetta Agricultural Research Center (HARC) in 2013/2014 cropping season from June to December 2013. Holetta (West Shewa Zone of Oromia Region) is located at latitude $9^{\circ} \mathrm{N}$ and longitude $38^{\circ} \mathrm{E}$, altitude of $2400 \mathrm{~m}$ a.s.l situated $30 \mathrm{~km}$ West of Addis Ababa. It is one of the representatives of oil seed Brassica growing areas in the central highlands of Ethiopia (Nigussie and Mesfin, 1994). The area has mean annual rainfall of $1059 \mathrm{~mm}$ and temperatures of $23^{\circ} \mathrm{C}$ (maximum) and $8^{\circ} \mathrm{C}$ (minimum). The soil type is Nitisols with soil ph in the range of $6.0-7.5$ (Nigussie and Mesfin, 1994).

\section{Description of Test Materials}

A total of forty-nine mustard land races that include one local check and one standard check were used in this study. The majority of the accessions represent the national collection from different major mustard growing regions of the country and that are maintained at Holetta Agricultural Research Center. The accessions were obtained kindly from Holetta agricultural research center of highland oil crops improvement program. The details of the accessions used in the experiment are given in Table 1.

Table 1. List of 49 Ethiopian mustard genotypes used in the study and their origin

\begin{tabular}{|c|c|c|c|c|c|}
\hline No & Accession number & Area of collection & Altitude(m) & Latitude & Longitude \\
\hline 1 & PGRC/E20001 & West Wollega/Arjo & 2420 & $08-44-00 \mathrm{~N}$ & $36-40.00 \mathrm{E}$ \\
\hline 2 & $" \quad 20002$ & Bale Zone/Kitu & 2500 & $06-.59 .00 \mathrm{~N}$ & $39-12-00 \mathrm{E}$ \\
\hline 3 & 20004 & South Gonder/Liba & 1980 & $12-.05-00 \mathrm{~N}$ & $37-44-00 \mathrm{E}$ \\
\hline 4 & 20005 & SouthGonder/Debretabor & 1830 & $11-57-00 \mathrm{~N}$ & $37-37-00 \mathrm{E}$ \\
\hline 5 & 20006 & South Gonder/Debretabor & 1980 & $11-50-00 \mathrm{~N}$ & 37-37_00E \\
\hline 6 & 20007 & North Gonder/Woger/Dabat & 2500 & $*$ & $*$ \\
\hline 7 & 20017 & West Gojiam /Awi /Dangila & 1980 & $11-.20-00 \mathrm{~N}$ & $36-58-00 \mathrm{E}$ \\
\hline 8 & 20056 & West Shewa/Jibatenamecha & 2200 & $09-01-00 \mathrm{~N}$ & $38 .-20-00 \mathrm{E}$ \\
\hline 9 & 20065 & West Shewa/Jibatena mecha & 2200 & $08-58-00 \mathrm{~N}$ & $37-30.00 \mathrm{E}$ \\
\hline 10 & 20066 & West Shewa/Ambo & 1950 & $08-.59 .00 \mathrm{~N}$ & $37-48-00 \mathrm{E}$ \\
\hline 11 & 20067 & West Shewa/Ambo & 2010 & $08-.58-00 \mathrm{~N}$ & $37-52-00 \mathrm{E}$ \\
\hline 12 & 20076 & SNNP/Wenago & 1853 & $06-23-00 \mathrm{~N}$ & $38-20-00 \mathrm{E}$ \\
\hline 13 & 20077 & South East Tigray/Inderta & 2000 & $13-29-00 \mathrm{~N}$ & 39-30.00E \\
\hline 14 & 20112 & West Gojam/JabiTehnan & 1980 & $10-.39 .00 \mathrm{~N}$ & $37-24-00 \mathrm{E}$ \\
\hline 15 & 20117 & West Shewa/Jibatnamecha & 2050 & $08-.58-00 \mathrm{~N}$ & $38-01-00 \mathrm{E}$ \\
\hline 16 & 20127 & West Shewa/chelia & 1700 & $09-03-00 \mathrm{~N}$ & $37-10-00 \mathrm{E}$ \\
\hline 17 & 20133 & West Shewa/Menagesha & 2600 & $09-11-00 \mathrm{~N}$ & 39-09.00E \\
\hline 18 & 20134 & West Shewa/Jibat & 2200 & $08-.58 .00 \mathrm{~N}$ & $37-30-00 \mathrm{E}$ \\
\hline 19 & 20146 & West Gojam/Bahirdarzuria & 1980 & $11-.25-00 \mathrm{~N}$ & $37-12-00 \mathrm{E}$ \\
\hline 20 & 20165 & West Gojiam/Awi/Dangila & 1980 & $11-20-00 \mathrm{~N}$ & $36-58-00 \mathrm{E}$ \\
\hline 21 & 20166 & West Gojiam/Awi/Dangila & 1980 & $11-20-00 \mathrm{~N}$ & $36-58.00 \mathrm{E}$ \\
\hline 22 & 21008 & Arsi/Gedeb & 2380 & $07-.12 .00 \mathrm{~N}$ & $38-09-00 \mathrm{E}$ \\
\hline 23 & 21012 & West shewa/Dendi & 2900 & $09-.14-00 \mathrm{~N}$ & $38-53-00 \mathrm{E}$ \\
\hline 24 & 21017 & West Shewa/Gendbert & 2470 & $09-43-00 \mathrm{~N}$ & $37-46-00 \mathrm{E}$ \\
\hline 25 & 21026 & West Gojiam Awi/Dangila & 2000 & $11-18-00 \mathrm{~N}$ & $36-58.00 \mathrm{E}$ \\
\hline 26 & 21035 & West Gojam/Sekela & 2540 & $10-.50-00 \mathrm{~N}$ & $37-04-00 \mathrm{E}$ \\
\hline 27 & 21037 & West Gojiam/Awi/Dangila & 2165 & $11-.14-00 \mathrm{~N}$ & $36-51-00 \mathrm{E}$ \\
\hline 28 & 21068 & Bale/Adaba & 2500 & $07-01-00 \mathrm{~N}$ & $39-25-00 \mathrm{E}$ \\
\hline 29 & 21157 & SNNP /South omo & 2830 & $06-19-00 \mathrm{~N}$ & $38-52-00 \mathrm{E}$ \\
\hline 30 & 21225 & East Gojam/Enemay & 2000 & $10-.32-00 \mathrm{~N}$ & 38-09-00E \\
\hline 31 & 208411 & West Gonder/Debretabor & 2150 & $11-.50-00 \mathrm{~N}$ & $37-35-00 \mathrm{E}$ \\
\hline 32 & 229665 & West Gojam/Burie & 2050 & $10-33-00 \mathrm{~N}$ & $37-34-00 \mathrm{E}$ \\
\hline
\end{tabular}


Multivariate Analysis of Genetic Divergent of Ethiopian Mustard (Brasica Carinata A. Braun) Landraces in Relation to Oil Quality Component Traits

\begin{tabular}{|c|c|c|c|c|c|}
\hline 33 & 237048 & Arsie-Robe & 2350 & $07-08-00 \mathrm{~N}$ & $40-00.00 \mathrm{E}$ \\
\hline 34 & PGRC/E 241907 & South Gonder/Fogera & 1825 & $12-.01-00 \mathrm{~N}$ & $37-43-00 \mathrm{E}$ \\
\hline 35 & " 241910 & South Gonder/Farta & 2289 & $11-.49-00 \mathrm{~N}$ & $38-00-00 \mathrm{E}$ \\
\hline 36 & 242856 & Arsi zone /Sherka & 2360 & $07-32-64 \mathrm{~N}$ & $39-37-87 \mathrm{E}$ \\
\hline 37 & 242858 & Arsi zone /Sherka & 2360 & $07-34-27 \mathrm{~N}$ & $39-31-24 \mathrm{E}$ \\
\hline 38 & 243738 & South Wollo/Desiezuria & 2928 & $11-08-00 \mathrm{~N}$ & $39-13-00 E$ \\
\hline 39 & 243739 & South Wollo/Tenta & 2950 & $11-.14-00 \mathrm{~N}$ & $39-15-00 \mathrm{E}$ \\
\hline 40 & 21256 & West Gojam/Bahirdarzuria & 1940 & $11-16-00 \mathrm{~N}$ & 36-59-00E \\
\hline 41 & 243750 & Wollo/kalu & 2020 & $11-45-00 \mathrm{~N}$ & $39-47.00 \mathrm{E}$ \\
\hline 42 & 2243756 & South Gonder/ Debark & 3115 & $11-.08 .00 \mathrm{~N}$ & $37-56-00 \mathrm{E}$ \\
\hline 43 & 243761 & Gonder Zuria & 2050 & $12-.19-00 \mathrm{~N}$ & 37-33-00E \\
\hline 44 & 243763 & South Gonder/Kemkem & 2070 & $11-57-00 \mathrm{~N}$ & $37-37-00 \mathrm{E}$ \\
\hline 45 & 208556 & West Shewa/Adis Alem & 2200 & $*$ & $*$ \\
\hline 46 & 208585 & East Shewa/yerer & 1600 & $*$ & $*$ \\
\hline 47 & Yellow dodolla & Bale/Dodolla & 2500 & $06-.59-00 \mathrm{~N}$ & 39-12-00E \\
\hline 48 & (ZemX Yellow Dodolla ) & Cross & 2400 & $09-00-00 \mathrm{~N}$ & $38-00-00 \mathrm{E}$ \\
\hline 49 & Local check & Holetta area & 2400 & $09-00-00 \mathrm{~N}$ & $38-00-00 \mathrm{E}$ \\
\hline
\end{tabular}

Source: Holetta highland oil crops research program, ${ }^{*}=$ information not found

\section{Experimental Design, Management and Season}

The experiment was executed from June 2013 to December 2013. The experiment was laid out in simple lattice design $7 X 7$ with two replications. A plot of four central rows each three-meter long and $30 \mathrm{Cm}$ spacing between rows were used for data collection. Each replication had seven blocks and each block was represented by seven plots. The path between blocks was $2 \mathrm{~m}$ and the spacing between plots with in sub-blocks was also $0.6 \mathrm{~m}$. Each entry was manually drilled, a rate of $10 \mathrm{~kg} / \mathrm{ha}$ and urea and phosphorous fertilizers were applied at the rates of $46 / 69 \mathrm{~kg} / \mathrm{ha} \mathrm{N} / \mathrm{P}_{2} \mathrm{O}_{5}$ respectively following the national recommendations. All other recommended agronomic and cultural practices were carried out following practices described by Adefris(2005).

\section{Data Collected}

The data were collected for seven Ethiopian mustard seed oil quality traits. The seed oil content was determined by nuclear magnetic resonance spectroscope (NMRS). It was measured as percentage of fats in the seed. A sample of $22 \mathrm{~g}$ of seeds was dried in an oven for 2 and half an hour at $78^{\circ \mathrm{C}}$ and cooled for 30 minutes. Then the oil content of the seed were measured using the procedures of Robbelen et al., (1989). The fatty acid composition of the seed was determined using Near Infrared Spectroscopy (NIRS) using the procedure of Theies (1971). The major fatty acids such as palmaic, stearic, oleic, linoleic, linolenic, and erucic acid were considered in the study. Each was measured as percentage of total fatty acid and was performed on $3 \mathrm{~g}$ of samples using Foss NIRS 5000 in the 11082492 ranges with an $8 \mathrm{~nm}$ steps. The spectrum of each sample was taken by scanning (Win Scan) version 15, 2000 intra soft international LL.C. Data Analysis of multivariate analysis such as Cluster analysis and principal component analysis genotypic values was performed by canonical roots method using procedures of SAS (SAS Institute, 2008) version 9.20.Software to group sets of genotypes into possible homogenous classes. The genetic distances between clusters was estimated by Mahalanobis's (1936) $\mathrm{D}^{2}$ statistics using the same software as clustering as:

$$
D^{2} i j=\left(\bar{X}_{i}-\bar{X}_{j}\right)^{1} C O V^{-1}\left(\bar{X}_{i}-\bar{X}_{j}\right)
$$

Where, $\boldsymbol{D}^{2} i j=$ Total generalized distance between class $\mathrm{i}$ and $\mathrm{j}$

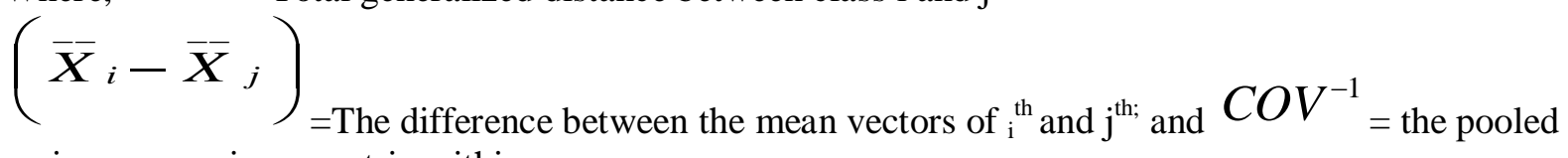
variance-covariance matrix within groups.

The significance of $\mathrm{D}^{2} \mathrm{ij}$ values for pairs of clusters were tested using the calculated values of chisquare $\left(\mathrm{x}^{2}\right)$ at, $0.01 \%$, and $5 \%$ probability level. The test was done against the tabulated values of $\mathrm{x}^{2}$ for 
' $\mathrm{P}$ ' degrees of freedom, where $\mathrm{P}$ is the number of quantitative characters considered (Singh and Chaundhary, 1985)

\section{RESUlTS AND DiSCUSSION}

The analysis of variance for the 7 oil quality traits studied is given in Table 2.The analysis of variance showed that there were highly significant differences among genotypes for all quality traits compared. The significant difference indicates the existence of genetic variability among the accessions that is important for the future selection and breeding program. Similarly Yared,(2010) studied thirty six genotypes of mustard for oil content, palmatic, stearic, oleic, linoleic linolenic and erucic acid of traits found the same result. Variation in fatty acid compositions among the Ethiopian mustard germplasm accessions has also been reported by Nigussie et al., (1999) and Adefris(2005).

Table 2. Mean squares for different sources of variations for 7 oil quality traits of 49 Ethiopian mustard

\begin{tabular}{|l|l|l|l|l|}
\hline Characters & $\begin{array}{l}\text { Genotype } \\
(48)\end{array}$ & $\begin{array}{l}\text { Block } \\
(12)\end{array}$ & Replication(1) & $\begin{array}{l}\text { Intera-block } \\
(36)\end{array}$ \\
\hline Oil content & $3.4446^{* *}$ & 1.3825 & 217.51 & 1.1283 \\
\hline Palmic acid & $0.2691^{* *}$ & 0.0661 & 0.0072 & 0.05179 \\
\hline Stearic acid & $0.034^{* *}$ & 0.0073 & 0.0002 & 0.00757 \\
\hline Oleic acid & $2.2211^{* *}$ & 1.1983 & 4.1164 & 0.598 \\
\hline Linoleic acid & $2.2839^{* *}$ & 1.5701 & 4.1291 & 0.4673 \\
\hline Linolenic acid & $11.342^{* *}$ & 1.444 & 7.3909 & 1.3781 \\
\hline Erucic acid & $7.165^{* *}$ & 4.959 & 23.078 & 1.846 \\
\hline
\end{tabular}

** significant at $\mathrm{p}=0.05$ and 0.01 significance level, respectively

The mean and range values of the studied 49 genotypes of Ethiopian mustard for oil quality parameters are presented in Table 3. Regarding seed oil quality traits, the palmaic, stearic, oleic, linoleic, linolenic, and erucic acid of the genotypes ranged from 2.76 to $4.55,0.64$ to $1.17 \%, 6.91$ to $11.51,15.59$ to $20.09,7.61$ to 17.39 and 40.09 to 49.07 respectively. The highest palmic mean value was shown by the genotype PGRC/E21225 where as the lowest was by the genotype PGRC/E 20065. The highest value of stearic (1.17)was shown by the genotype PGRC/E 208411 and the lowest (0.64) by genotype PGRC/E 21008.The highest value of oleic acid(11.51) was shown by genotype PGRC/E 20017, whereas the lowest(6.91) was by genotype (zem x yellow). The highest value (20.09) for linoleic was recorded by genotype PGRC/E 21225 and the lowest (15.59) was recorded by genotype PGRC/E 21017. The highest palmatic and linoleic mean value was recorded by the genotype PGRC/E 21225.

The highest mean value (17.39) for linolenic was recorded by genotype PGRC/E 21008 and the lowest (7.61) was recorded by genotype PGRC/E 208411. Generally; these results indicate that those traits which had wide range of variations will serve for breeding and selection for improvement of the trait desired. A wide range of variations recorded for traits for example for erucic acid. The highest erucic acid was recorded for the genotype PGRC/E 20077 and the lowest was recorded for the genotype PGRC/E 20065.

Table 3. Mean and range values of tested genotypes for oil quality traits determined by NIRS

\begin{tabular}{|l|l|l|l|l|l|l|l|}
\hline \multicolumn{2}{|l|}{ Genotypes } & Palmic & Stearic & Oleic & Linoleic & Linolenic & Erucic acid \\
\hline 1 & PGRC/E20001 & 3.96 & 0.93 & 9.47 & 16.99 & 10.94 & 45.38 \\
\hline 2 & " 20002 & 3.83 & 0.72 & 8.16 & 19.21 & 15.18 & 45.95 \\
\hline 3 & " 20004 & 3.64 & 1.05 & 9.90 & 16.80 & 10.05 & 43.70 \\
\hline 4 & " 20005 & 3.94 & 0.82 & 9.77 & 17.86 & 13.95 & 43.47 \\
\hline 5 & " 20006 & 3.46 & 0.97 & 9.50 & 16.88 & 10.83 & 43.53 \\
\hline 6 & " 20007 & 3.60 & 0.86 & 8.74 & 16.96 & 12.33 & 44.63 \\
\hline 7 & " 20017 & 3.40 & 1.05 & 11.51 & 16.82 & 10.54 & 40.47 \\
\hline 8 & " 20056 & 3.79 & 0.98 & 9.50 & 17.24 & 10.18 & 44.13 \\
\hline 9 & PGRC/E 20065 & 2.76 & 1.14 & 9.75 & 15.99 & 9.42 & 40.09 \\
\hline 10 & " 20066 & 4.09 & 1.03 & 10.42 & 16.20 & 10.38 & 44.30 \\
\hline
\end{tabular}


Multivariate Analysis of Genetic Divergent of Ethiopian Mustard (Brasica Carinata A. Braun) Landraces in Relation to Oil Quality Component Traits

\begin{tabular}{|c|c|c|c|c|c|c|c|}
\hline \multicolumn{2}{|c|}{ Genotypes } & \multirow{2}{*}{\begin{tabular}{|l} 
Palmic \\
4.09
\end{tabular}} & \multirow{2}{*}{\begin{tabular}{|l|} 
Stearic \\
0.95
\end{tabular}} & \multirow{2}{*}{\begin{tabular}{|l|} 
Oleic \\
9.25
\end{tabular}} & \multirow{2}{*}{\begin{tabular}{|l|} 
Linoleic \\
16.96
\end{tabular}} & \multirow{2}{*}{\begin{tabular}{|l|} 
Linolenic \\
12.76
\end{tabular}} & \multirow{2}{*}{\begin{tabular}{|l} 
Erucic acid \\
45.70
\end{tabular}} \\
\hline 11 & 20067 & & & & & & \\
\hline 12 & 20076 & 3.47 & 1.02 & 9.30 & 17.00 & 10.24 & 43.46 \\
\hline 13 & 20077 & 4.42 & 0.67 & 7.20 & 18.30 & 16.44 & 49.07 \\
\hline 14 & 20112 & 3.56 & 1.00 & 9.51 & 16.75 & 10.67 & 42.25 \\
\hline 15 & 20117 & 4.02 & 1.09 & 9.51 & 16.31 & 9.24 & 43.68 \\
\hline 16 & 20127 & 4.08 & 1.02 & 11.36 & 16.83 & 10.39 & 41.83 \\
\hline 17 & 20133 & 4.51 & 0.90 & 9.56 & 19.37 & 13.57 & 45.66 \\
\hline 18 & 20134 & 4.26 & 1.02 & 10.27 & 16.12 & 10.07 & 44.22 \\
\hline 19 & 20146 & 3.85 & 0.91 & 9.73 & 18.42 & 12.61 & 42.97 \\
\hline 20 & 20165 & 3.65 & 0.95 & 10.17 & 16.35 & 11.46 & 42.41 \\
\hline 21 & 20166 & 3.81 & 0.93 & 9.98 & 17.00 & 12.28 & 43.95 \\
\hline 22 & " 21008 & 3.61 & 0.64 & 7.50 & 18.65 & 17.39 & 46.41 \\
\hline 23 & " 21012 & 3.35 & 1.10 & 10.73 & 16.98 & 9.71 & 40.61 \\
\hline 24 & " 21017 & 3.67 & 1.10 & 10.39 & 15.59 & 9.27 & 43.03 \\
\hline 25 & " 21026 & 3.78 & 1.07 & 10.41 & 16.72 & 9.21 & 42.57 \\
\hline 26 & " 21035 & 3.96 & 0.91 & 10.29 & 17.96 & 12.26 & 43.74 \\
\hline 27 & " 21037 & 3.69 & 1.05 & 10.52 & 17.72 & 10.54 & 41.80 \\
\hline 28 & " 21068 & 3.19 & 0.72 & 7.24 & 17.42 & 14.78 & 46.82 \\
\hline 29 & " 21157 & 3.57 & 0.92 & 10.07 & 17.28 & 14.26 & 41.81 \\
\hline 30 & " 21225 & 4.55 & 0.79 & 9.72 & 20.09 & 15.17 & 44.68 \\
\hline 31 & " 208411 & 3.32 & 1.17 & 10.75 & 17.32 & 7.61 & 42.63 \\
\hline 32 & " 229665 & 4.13 & 1.05 & 9.69 & 16.98 & 9.78 & 43.28 \\
\hline 33 & " 237048 & 4.27 & 0.71 & 7.32 & 18.76 & 12.70 & 48.28 \\
\hline 34 & " 241907 & 3.78 & 0.93 & 9.04 & 16.83 & 10.35 & 45.03 \\
\hline 35 & " 241910 & 3.84 & 0.94 & 10.33 & 17.40 & 12.50 & 44.29 \\
\hline 36 & " 242856 & 4.09 & 0.85 & 8.97 & 18.85 & 13.48 & 43.62 \\
\hline 37 & " 242858 & 4.11 & 0.94 & 10.41 & 17.78 & 11.65 & 43.67 \\
\hline 38 & " 243738 & 4.01 & 0.83 & 9.13 & 18.98 & 15.07 & 45.31 \\
\hline 39 & " 243739 & 4.23 & 0.81 & 8.14 & 18.85 & 14.96 & 46.98 \\
\hline 40 & " 21256 & 3.50 & 1.06 & 9.76 & 16.79 & 8.75 & 41.67 \\
\hline 41 & " 243750 & 3.47 & 0.76 & 8.48 & 19.12 & 15.12 & 44.18 \\
\hline 42 & " 243756 & 3.66 & 1.01 & 10.01 & 16.97 & 10.32 & 41.17 \\
\hline 43 & " 243761 & 3.53 & 0.93 & 9.44 & 17.44 & 11.48 & 43.29 \\
\hline 44 & " 243763 & 3.95 & 0.87 & 9.92 & 17.32 & 11.86 & 42.60 \\
\hline 45 & " 208556 & 3.72 & 0.89 & 9.06 & 16.97 & 13.84 & 43.91 \\
\hline 46 & " 208585 & 3.65 & 0.87 & 8.49 & 17.34 & 15.73 & 44.22 \\
\hline 47 & Yellow dodolla & 3.21 & 0.93 & 8.02 & 17.52 & 14.55 & 43.29 \\
\hline 48 & (Zem X YD) ) & 3.57 & 0.65 & 6.91 & 18.40 & 16.99 & 46.32 \\
\hline \multirow[t]{5}{*}{49} & Local check & 4.44 & 0.85 & 9.57 & 18.43 & 13.10 & 45.69 \\
\hline & Range & $2.76-4.55$ & $0.64-1.17$ & $6.91-11.51$ & $15.59-20.09$ & $7.61-17.39$ & $40.1-49.07$ \\
\hline & Mean & 3.8 & 0.92 & 9.44 & 17.5 & 12.16 & 43.91 \\
\hline & $\mathrm{CV}(\%)$ & 5.99 & 9.39 & 8.19 & 3.91 & 9.65 & 3.09 \\
\hline & $\operatorname{LSD}(0.05)$ & 0.46 & 0.18 & 1.66 & 1.50 & 2.36 & 2.96 \\
\hline
\end{tabular}

$\mathrm{CV}=$ coefficient of variation, $\mathrm{LSD}=$ least significance different

Clustering based on oil quality traits produced clear grouping of the 49 genotypes into four clusters Table4. The highest $61.22 \%$ of the genotypes were grouped under C1 followed by $24.49 \%$ in C3 and $12.24 \%$ in C2, 2.04\% in C4. In quality traits clustering, Cluster 1 the largest of all included 30(61.22 $\%)$ genotypes that comprised nine genotypes each from West Shewa, West Gojiam and South and 
North Gonder, one genotypes each from Southern Nation Nationalities, West Wollega and Arsi zone respectively. The second cluster (cluster2) comprises6 (12.24\%) genotypes 2 from Bale zone, one genotype each from Arsie zone ,South Wollo, South Tigray and cross. Local check and standard check was also included in cluster 3. Cluster3 comprised 12(24.48\%) genotypes. Four Genotypes were from West and East Shew, 2genotypes from West and East Gojiam and South Wollo, 1genotype each from Southern Nations nationalities and Bale zone. There are also genotypes with the same geographical origin but grouped in different clusters, and genotypes with different geographic origin groped in the same cluster. Solitary genotype in C4 was Arsi zone origin.

Table 4. Distribution of 49 Ethiopian mustard genotypes in different clusters based on their quality traits

\begin{tabular}{|l|l|l|}
\hline Cluster & $\begin{array}{l}\text { No. of } \\
\text { genotypes }\end{array}$ & $\begin{array}{l}\text { Genotypes included by code and origin } \\
\text { 10(Shewa),18(Shewa),5(Gonder),12(Sidamo),26(Gojam),37(Arsie),21(Gojam),35( } \\
\text { Gonder),3(Gonder),32(Gojam),1(Wolega),34(Gonder),8(Shewa),43(Gonder),44(Go } \\
\text { nder),14(Gojam),20(Gojam),27(Gojam),42(Gonder),7(Gojam),23(Shewa),24(Shew } \\
\text { a),25(Gojam)),6(Gonder),11(Shewa),15(Shewa),16(Shewa),40(Gojam), } \\
\text { 31(Gonder), 9(Shewa). }\end{array}$ \\
\hline ClusterII & 6 & 22(Arsie), 48(cross),2(Bale), 39(Wollo), 28(Bale), 13(Tigray) \\
\hline ClusterIII & 12 & $\begin{array}{l}\text { 17(Shewa),49(Shewa), 4(Gonder),45(Shewa),19(Gojam),36(Arsie), 38(wollo), } \\
\text { 41(Wollo), 46(Shewa), 47(Bale), 30(Gojam), 29(Sidamo). }\end{array}$ \\
\hline Cluster IV & 1 & 33(Arsie). \\
\hline
\end{tabular}

Intra-class average genetic divergence of Ethiopian mustard for quality traits is shown in Table5.Genotypes of Cluster 4 showed the highest mean palmatic fatty acid content than other clusters. On the other side highest stearic, oleic and low erucic fatty acid content was found in Cluster 1 than other clusters. High linoleic and erucic acid content showed in Cluster 4 Genotypes and high oil content with low erucic acid was cluster in Cluster 1.

Table 5. Clusters mean for quality traits of the Ethiopian Mustard genotypes

\begin{tabular}{|l|c|c|c|c|}
\hline & \multicolumn{4}{|c|}{ Cluster } \\
\hline Traits & Cluster 1 & \multicolumn{1}{|c|}{ Cluster2 } & Cluster3 & Cluster4 \\
\hline & Mean & Mean & Mean & Mean \\
\hline Palmitic & 3.73 & 3.81 & 3.92 & 4.27 \\
\hline Stearic & 1.00 & 0.70 & 0.86 & 0.71 \\
\hline Oleic & 9.99 & 7.53 & 9.21 & 7.32 \\
\hline Linoleic & 16.9 & 18.47 & 18.35 & 18.76 \\
\hline Linolenic & 10.57 & 15.96 & 14.20 & 12.70 \\
\hline Erucic acid & 43.10 & 46.93 & 44.07 & 48.28 \\
\hline Oil content & 43.20 & 42.72 & 42.42 & 41.50 \\
\hline
\end{tabular}

The pair wise generalized squared distance (D2) among the clusters based on quality traits are presented in Table 6. Genetic distances were highly significant among most of the clusters. The highest genetic distance was recorded between Cluster 3 and Cluster 4 (38.2) followed by Cluster 1 and Cluster 4 (37.7), and Cluster 1 and Cluster 2 (33.3). The genetic divergence between Cluster 1 and Cluster 2, Cluster 1 and Cluster 4, Cluster 2 and Cluster 4, Cluster 3 and Cluster 4 were also highly significant. Genetic distances of genotypes based on quality traits between Cluster 2 and Cluster 3 were only non- significant, indicating close relationship among the genotypes.

Table 6. Pair wise generalized squared distance (D2) among 49 genotypes of Ethiopian mustard in four clusters based on their quality traits

\begin{tabular}{|l|l|l|l|l|}
\hline \multirow{2}{*}{ Cluster } & \multicolumn{4}{|c|}{ Cluster } \\
\cline { 2 - 6 } & Cluster 1 & Cluster 2 & Cluster 3 & Cluster4 \\
\hline Cluster 1 & 0 & $33.3^{* *}$ & $16.5^{* *}$ & $37.7^{* *}$ \\
\hline Cluster 2 & & 0 & $11.1 \mathrm{~ns}$ & $22.1^{* *}$ \\
\hline Cluster 3 & & & 0 & $38.2^{* *}$ \\
\hline Cluster 4 & & & & 0 \\
\hline
\end{tabular}

In order to assess the patterns of variations, principal component analysis (PCA) was done by considering 7 traits of quality. A principal component analysis is presented in Tables 7. Principal 
component analysis using values for quality traits showed that $94.96 \%$ of the variation was depicted by the first four principal components. $57.58 \%$ of the variation was portrayed by the first principal component in which linolenic, erucic acid, lenoleic and palmatic were the major contributors. Stearic, oleic and oil content had negative weight. Additional variation of $18.32 \%$ was revealed by the second principal component which accounted mainly for palmatic and oleic acid. Oil content had the highest negative weight in this principal component. Other additional variations of $10.96 \%$ and $8.10 \%$ in respective of the third and fourth principal component have been revealed. Oil content in the third and linoleic in the fourth principal component were the major positive contributors for the respective variations mentioned. In summery the total variation attributed by individual trait effect ranged between $\pm 0.616-0.709$ which is small and hence, it is the cumulative effects of the individual traits principally responsible for cluster formation. However, traits which had relatively greater weight in the first principal component largely contributed to the total variation and they were accountable for differential grouping of genotypes.

Table 7. Component scores of the first four principal components of 49 genotypes of Ethiopian mustard based on their quality traits

\begin{tabular}{|l|l|l|l|l|}
\hline & \multicolumn{5}{|c|}{ Component scores } \\
\hline Traits & $\begin{array}{l}\text { Principal } \\
\text { component } 1\end{array}$ & $\begin{array}{l}\text { Principal } \\
\text { component 2 }\end{array}$ & $\begin{array}{l}\text { Principal component } \\
3\end{array}$ & $\begin{array}{l}\text { Principal } \\
\text { component 4 }\end{array}$ \\
\hline Palmitic & 0.224 & 0.612 & 0.624 & -0.001 \\
\hline Stearic & -0.474 & 0.135 & 0.059 & -0.080 \\
\hline Oleic & -0.402 & 0.393 & 0.105 & 0.399 \\
\hline Linoleic & 0.402 & 0.182 & -0.112 & 0.605 \\
\hline Linolenic & 0.443 & -0.197 & -0.091 & 0.329 \\
\hline Erucic acid & 0.430 & 0.031 & 0.266 & -0.528 \\
\hline Oil content & -0.139 & -0.616 & 0.709 & 0.283 \\
\hline Eigen value & 4.03 & 1.23 & 0.77 & 0.57 \\
\hline Variance (\%) & 57.58 & 18.32 & 10.96 & 8.10 \\
\hline Cumulative (\%) & 57.58 & 75.90 & 86.86 & 94.96 \\
\hline
\end{tabular}

\section{CONClusion}

In this study, 49 Ethiopian mustard land races acquired from diverse zones/regions of Ethiopia were evaluated in simple lattice design with two replications at Holetta Agricultural Research Center, West Shewa zone, with the objectives of estimating the genetic diversity through oil quality component traits.

The univariate analysis of oil quality component traits has shown the highest significant differences for all oil quality component traits compared.

Multivariate analyses of genetic divergence among genotypes have resulted in the formation of four clusters, and have shown the presence of genetic variability for further selection and breeding. Genetic distances among most clusters were significant from which selection of parents may be made for crossing in order to obtain genetic recombination and transgressive segregants. Parental material for improvement of seed oil of Ethiopian mustard may be obtained from those genotypes which have high oleic but low erucic acid content in the seed oil in $\mathrm{C} 1$. On the other hand, genotype in $\mathrm{C} 4$ has shown highest erucic acid content in its seed oil which may be used as sources of genes in efforts of breeding for industrial purposes. Genotypes formed in $\mathrm{C} 1$ could also be used for their high oil content. From the present investigation, we could also found that geographical diversity could not necessarily be an index of genetic variability, and the factors other than geographic diversity such as genetic drift, selection pressure and environment may be responsible for differential grouping of genotypes. The present study revealed the presence of considerable variability among genotypes for all traits compared. These conditions indicate that there is good opportunity to improve these characters using the tested genotypes. 
It is also suggested that further work on crossing and pedigree selection among the genotypes studied is needed in order to get the desired level of oleic, linoleic, linolenic and erucic acid for both food and non-food industry.

\section{REFERENCES}

[1] Adefris Teklewold. 2005. Diversity Study Based on Quality Traits and RAPD Markers and Investigation of Heterosis in Ethiopian Mustard. Ph.D. diss. Georg-August Univ. of Göttingen, Germany. 161p.

[2] CSA (Central Statistical Authority). 2013/14. Report on land utilization: Private peasant holdings, 'Meher' season. Statistical bulletin. Addis Ababa, Ethiopia.

[3] Doweny R.K. and G. RÖbbelen. 1989. Brassica Species. In RÖbbelen G, Doweny RK and Ahri A (eds) Oil crops of the world. McGraw-Hill New York. pp. 339-359

[4] EARO (Ethiopian Agricultural Research Organization). 2000. Crop Research Directorate, High land oil crops research strategy, Addis Ababa, Ethiopia.

[5] Getinet, A., G. Rakow, J.P. Raney and R.K. Downey. 1994. Development of zero erucic acid Ethiopian mustard through an interspecific cross with zero erucic acid oriental mustard. Can. $J$. Plant Sci. 74: 793-795

[6] Gomez-Campo, C. and S. Prakash. 1999. Origin and domestication of the Brassica. pp. 33-58. In: Gomez-Campo C (ed.). Biology of Brassica Coenospecies. Elsevier, Amsterdam.

[7] Hemingway, J.S. 1976. Mustards Brassica species and Sinapsis alba (Cruciferae). In: Evolution of Crop Plants. N.W. Simmounds (ed.) Longan. London. 339p.

[8] Mahalanobis, P.C. 1936. On the generalized distance in statistics.Proc. Natl. Sci. India B. 2: 4955

[9] Nigussie, A. and H. Becker. 2001. Variation and inheritance of erucic acid content in Brassica carinata germplasm collections from Ethiopia. Plant Breeding, 120: 33 1-335

[10] Nigussie, A., H. Becker and G. Gebeyehu. 1999. Genetic variability in Ethiopian mustard (Brassica carinata A. Braun) for quality characteristics. $10^{\text {th }}$ International Rapeseed Congress, Canberra, Australia.

[11] Nigussie Alemayehu and Mesfin Abebe. 1994. Relative importance of some managmnet factors in seed and oil yields of Ethiopian mustasrd (Brasica carinata Braun.) and Rapeseed (Brasica napus L.). Ethiop. J. Agric. Sci. 14: 27-36

[12] Robbelen,G.R.K.Doweny and A.Ashri,1989. Oil crops of the world .McGraw-Hill,New York.

[13] SAS Institute INC., 2002- 2008. SAS*STAT, users guide, version 9.2, Cary N.C., SAS INC

[14] Singh, R.K. and B.D. Chaydhary. 1985. Biometrical methods in quantitative genetic analysis

[15] Thies, W., 1971. Schnelle undeinfeche Analysen der fettsaurezu sammensetzung in einzlenen Raps-|Kotyledonen.Z.Pflanzenzuchtg., 65:181-202.

[16] U.N. 1935. Genome analysis in Brassica with special reference to the experimental formation of $B$. napus and peculiar mode of fertilization. Jpn. J. Bot. 9: 389-452

[17] Yared Semahegn. 2010. Genetic diversity and Relationship among Association amongEthiopian mustard (Brassica carinata A. Braun) genotypes based on their agronomic and quality Traits in at Holetta Agricultural research,. An M.Sc. Thesis Presented to the School of Graduate Studies of Jima University. 75p. 